\title{
The effect of self-scrutiny on improving women's self-esteem: A case study of Esfahan women
}

\author{
Farzaneh Monjezi $^{a^{*}}$, Mohammad Reza Iravani ${ }^{\text {b }}$, Mostafa Rajabi ${ }^{\mathrm{c}}$ and Hajar Jannesari ${ }^{\mathrm{d}}$
}

\begin{abstract}
${ }^{a}$ Counseling advisor, Counseling group, Research \& Science, Khouzestan Branch, Islamic Azad University, Khouzestan, Iran ${ }^{b}$ Assistant Professor, Department of Social Work, Islamic Azad University Khomeinishahr Branch, Daneshjou Blvd, Iran 'Assistant Professor, Department of Economic, Islamic Azad University of Khomeinishahr, Islamic Azad University Khomeinishahr Branch, Daneshjou Blvd, Iran

${ }^{d}$ MS Student, Counselling Department, Islamic Azad University of Khomeinishahr, Khomeinishahr Branch, Daneshjou Blvd, Iran

C H R O N I C L E

Article history:

Received October 20, 2012

Received in revised format

19 February 2013

Accepted 28 February 2013

Available online

March 12013

Keywords:

Self-scrutiny

Self-esteem

Esfahan

\section{A B S T R A C T}

The proposed study of this paper investigates the effect of self-scrutiny on improving women's self-esteem among 50 women who live in city of Esfahan, Iran. There are five hypotheses associated with the proposed study of this paper, which investigate whether teaching selfscrutiny skills increase women's total, educational-vocational, general, social and family selfesteem. The proposed study of this paper uses three groups of pre-test post-test and control groups and it has been executed among 50 women aged 20-35 who lived in city of Esfahan, Iran based on Coopersmith questionnaire. The results of ANOVA test confirm all five hypotheses of this survey. In other words, scrutiny skills increase women's total, educationalvocational, general, social and family self-esteem after control group participate in our training programs.
\end{abstract}

\section{Introduction}

Self-esteem is a term implemented in psychology to demonstrate a person's overall emotional evaluation of his/ her own worth a judgment of oneself (Dubois \& Tevendale, 1999; Pavlova et al. , 2011). According to Seger et al. (2009) self-esteem is the positive or negative evaluations of the self, as in how someone feels about it. There are different studies on learning the effects of various factors on improving self-esteem. Haddock and Gebauer (2011) reported that self-affirmation was particularly efficient for defensive self-esteem individuals in alleviating actual-ideal selfdiscrepancies. DeHart and Pelham (2007) reported that trait explicit self-esteem and self-concept could be moderated the within-person association between daily negative events and state implicit

Corresponding author. Tel: +989131707319

(E-mail addresses: fm.esfahani@gmail.com (F. Monjezi)

(C) 2013 Growing Science Ltd. All rights reserved.

doi: 10.5267/j.msl.2013.03.002 
self-esteem. In their survey, people with low trait explicit self-esteem or low self-concept clarity experienced reduction in state implicit self-esteem when they experienced negative life events.

Krizan (2008) explained that modern advances in implicit social cognition capable development of some techniques for testing less conscious aspects of self-worth. They reported that many respondents were aware of the self-relevant nature of the measure at the time of assessment. Jomeen and Martin (2005) investigated self-esteem and mental health during early pregnancy. They studied the predictive ability of self-esteem, assessed by self-report questionnaire, in predicting the psychological status of women early in pregnancy. They stated that personal self-esteem was a significant predictor of psychological status in terms of both anxiety and depression.

Rosenthal and Hooley (2010) investigated narcissism assessment in social-personality research and tried to find our whether the association between narcissism and psychological health result from a confound with self-esteem or not. They reported that inferences about narcissism and psychological health could require to be reinterpreted and emphasized the need for measures that correspond more directly to core components of narcissism. DiStefano and Motl (2009) performed an investigation on personality correlates of method effects due to negatively worded items on the Rosenberg SelfEsteem scale. They reported that method effect associated with negatively worded items could be more prominent for subjects possessing selected personality traits than for others. Elbedour et al. (2007) investigated the relationship between monogamous/polygamous family structure and the mental health of Bedouin Arab adolescents. Finally, Usborne and Taylor (2010) studied the role of cultural identity clarity for self-concept clarity, self-esteem, and subjective well-being.

The proposed study of this paper investigates the effect of self-scrutiny on improving women's selfesteem among 50 women who live in city of Esfahan, Iran. The organization of this paper first presents details of the proposed study in section 2 while section 3 presents the results and concluding remarks are given at the end to summarize the contribution of the paper.

\section{The proposed model}

The proposed study of this paper considers whether teaching self-scrutiny skills could increase selfesteem among women who live in city of Esfahan. Therefore, the proposed study considers the following hypotheses,

1. Teaching self-scrutiny skills increases women's total self-esteem.

2. Teaching self-scrutiny skills increases women's educational self-esteem.

3. Teaching self-scrutiny skills increases women's general self-esteem.

4. Teaching self-scrutiny skills increases women’s family self-esteem.

5. Teaching self-scrutiny skills increases women's social self-esteem.

The proposed study of this paper uses three groups of pre-test post-test and witness group and it has been executed among 50 women aged 20-35 who lived in city of Esfahan, Iran based on Coopersmith questionnaire (Coopersmith, 1967; Cooper, 2009). The questionnaire consists of 58 questions where questions $6,13,20,27,34,41,48$ and 55 are lie detector and five items are dedicated to four scales of general self-esteem, social self-esteem, family self-esteem and job and educational self-esteem and each question is categorized in terms of yes/no item. The survey is performed in ten sessions of 90 minutes where sessions are held on daily basis.

Fig. 1 demonstrates educational backgrounds of the participants in terms of years of educations. As we can observe from the results of Fig.1, nearly $60 \%$ of the participants in both groups had some university educations. Table 1 shows some basic statistics of the participants in terms of mean, standard deviation, etc. The average age for three groups of test and witness groups were $27.48 \pm 3.56$ 
and $27.08 \pm 4.48$, respectively. In our survey, $56 \%$ of the participants were married and $36 \%$ of them were single.

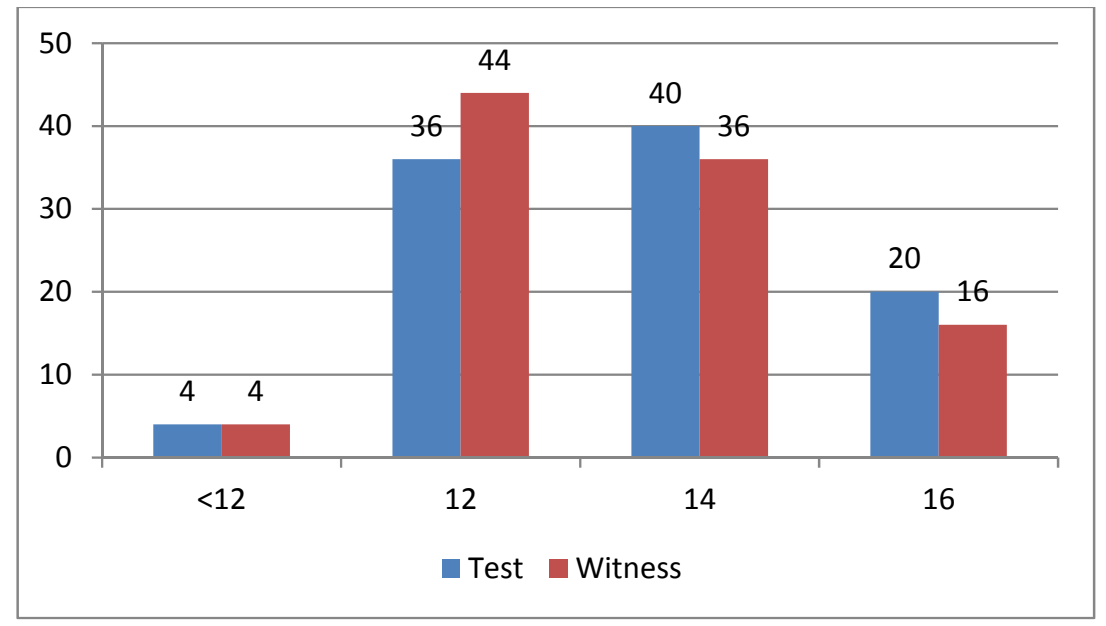

Fig. 1. Percentage of educational backgrounds in terms of years of educations

Table 1

Median and Std. Deviation scores of self-esteem

\begin{tabular}{ccccccc}
\hline \multirow{2}{*}{ Variable } & \multirow{2}{*}{ group } & Number & Pedian & Std. Deviation & Median & Post-test \\
& & Std. Deviation \\
\hline \multirow{2}{*}{ Total self-esteem } & Experiment & 25 & 24.36 & 2.09 & 30.48 & 2.75 \\
& Control & 25 & 24.20 & 2.36 & 23.76 & 2.66 \\
\hline \multirow{2}{*}{ Education- vocation self-esteem } & Experiment & 25 & 4.08 & .75 & 5.12 & .92 \\
& Control & 25 & 3.56 & .76 & 3.56 & .86 \\
\hline \multirow{2}{*}{ General self-esteem } & Experiment & 25 & 12.64 & 2.01 & 15.24 & 1.98 \\
& Control & 25 & 13.00 & 2.10 & 12.56 & 2.80 \\
\hline \multirow{2}{*}{ Family self esteem } & Experiment & 25 & 4.00 & .91 & 5.12 & 1.16 \\
& Control & 25 & 4.04 & .97 & 3.88 & 1.20 \\
\hline \multirow{2}{*}{ Social self esteem } & Experiment & 25 & 3.64 & .81 & 5.00 & .76 \\
& Control & 25 & 3.60 & 1.08 & 3.76 & .92 \\
\hline
\end{tabular}

As we can observe from the results of Table 1, the mean value of total self-esteem among experiment group is increased from 24.36 to 30.48 . Similar increase patterns are observed in other scales in terms of education-vocation, general, family and social self-esteem scales.

\section{The results}

In this section, we present details of our observations on testing various hypotheses of this survey using ANOVA test.

\subsection{The first hypothesis of the survey: Education-vocation}

The first hypothesis of this survey is associated with the relationship of the effect of self-scrutiny on improving total self-esteem. Table 2 demonstrates the results of our survey between two groups of test and witness.

\section{Table 2}

The results of ANOVA test between test and witness

\begin{tabular}{lccccc}
\hline Total self-esteem & Sum of Squares & df & Mean Square & F & Sig. \\
\hline Between Groups & 365.224 & 9 & 40.580 & 2.940 & .009 \\
Within Groups & 552.056 & 40 & 13.801 & & \\
\hline Total & 917.280 & 49 & & & \\
\hline
\end{tabular}


The results of Table 2 indicate that there is a meaningful difference between control and test groups when the level of significance is five or even one percent.

\subsection{The second hypothesis of the survey: Total self-esteem}

The second hypothesis of this survey is associated with the relationship of the effect of self-scrutiny on improving total education-vocation self-esteem. Table 3 demonstrates the results of our survey between two groups of test and witness.

Table 3

The results of ANOVA test between test and witness

\begin{tabular}{lccccc}
\hline Education-vocation self-esteem & Sum of Squares & df & Mean Square & F & Sig. \\
\hline Between Groups & 25.808 & 3 & 8.603 & 9.116 & .000 \\
Within Groups & 43.412 & 46 & .944 & & \\
\hline Total & 69.220 & 49 & & & \\
\hline
\end{tabular}

The results of Table 3 demonstrate that there is a meaningful difference between control and test groups when the level of significance is five or even one percent.

\subsection{The third hypothesis of the survey: General self-esteem}

The third hypothesis of this survey is associated with the relationship of the effect of self-scrutiny on improving total general self-esteem. Table 4 presents the results of our survey between two groups of test and witness.

\section{Table 4}

The results of ANOVA test between test and witness

\begin{tabular}{lccccc}
\hline General self-esteem & Sum of Squares & df & Mean Square & F & Sig. \\
\hline Between Groups & 181.192 & 9 & 20.132 & 4.209 & .001 \\
Within Groups & 191.308 & 40 & 4.783 & & \\
\hline Total & 372.500 & 49 & & & \\
\hline
\end{tabular}

The results of Table 4 demonstrate that there is a meaningful difference between control and test groups when the level of significance is five or even one percent.

\subsection{The fourth hypothesis of the survey: Family self-esteem}

The fourth hypothesis of this survey is associated with the relationship of the effect of self-scrutiny on improving total family self-esteem. Table 5 presents the results of our survey between two groups of test and witness.

Table 5

The results of ANOVA test between test and witness

\begin{tabular}{lccccc}
\hline Family self-esteem & Sum of Squares & df & Mean Square & F & Sig. \\
\hline Between Groups & 41.059 & 4 & 10.265 & 8.696 & .000 \\
Within Groups & 53.121 & 45 & 1.180 & & \\
\hline Total & 94.180 & 49 & & & \\
\hline
\end{tabular}

The results of Table 5 clearly show that there is a meaningful difference between control and test groups when the level of significance is five or even one percent. 


\subsection{The fifth hypothesis of the survey: Social self-esteem}

The fifth hypothesis of this survey is associated with the relationship of the effect of self-scrutiny on improving total family self-esteem. Table 6 presents the results of our survey between two groups of test and witness.

\section{Table 6}

The results of ANOVA test between test and witness

\begin{tabular}{lccccc}
\hline Social self-esteem & Sum of Squares & df & Mean Square & F & Sig. \\
\hline Between Groups & 20.292 & 4 & 5.073 & 6.817 & .000 \\
Within Groups & 33.488 & 45 & .744 & & \\
\hline Total & 53.780 & 49 & & & \\
\hline
\end{tabular}

The results of Table 6 clearly show that there is a meaningful difference between control and test groups when the level of significance is five or even one percent.

\section{Conclusion}

In this paper, we have presented a study to investigate the effect of self-scrutiny on improving women's self-esteem among 50 women who lived in city of Esfahan, Iran. There are five hypotheses associated with the proposed study of this paper, which studied whether teaching self-scrutiny skills increases women's total, educational-vocational, general, social and family self-esteem. The proposed study of this paper implemented three groups of pre-test post-test and control groups based on Coopersmith questionnaire. The results of ANOVA test have confirmed that self-scrutiny could influence positively on women's total, educational-vocational, general, social and family self-esteem.

\section{Acknowledgment}

The authors would like to thank the authors' feedbacks on earlier version of this paper, which contributed to quality of the paper.

\section{References}

Coopersmith, S. (1967). The antecedents of self-esteem. New York: W.H. Freeman.

Cooper, S.M. (2009). Associations between father-daughter relationship quality and the academic engagement of African American adolescent girls: Self-Esteem as a Mediator? Journal of Black Psychology, 35(4), 493- 516.

DeHart, T., \& Pelham, B.W. (2007). Fluctuations in state implicit self-esteem in response to daily negative events. Journal of Experimental Social Psychology, 43(1), 157-165.

DiStefano, C., \& Motl, R.W. (2009). Personality correlates of method effects due to negatively worded items on the Rosenberg Self-Esteem scale. Personality and Individual Differences, 46(3), 309-313.

Dubois, D.L., \& Tevendale, H.D. (1999). Self-esteem in childhood and adolescence: Vaccine or epiphenomenon?. Applied and Preventive Psychology, 8(2), 103-117.

Elbedour, S., Bart, W., \& Hektner, J. (2007). The relationship between monogamous/polygamous family structure and the mental health of Bedouin Arab adolescents. Journal of adolescence, 30(2), 213-230.

Haddock, G., \& Gebauer, J.E. (2011). Defensive self-esteem impacts attention, attitude strength, and self-affirmation processes. Journal of Experimental Social Psychology, 47(6), 1276-1284.

Jomeen, J., Martin, C.R. (2005). Self-esteem and mental health during early pregnancy. Clinical Effectiveness in Nursing, 9(1-2), 92-95. 
Krizan, Z. (2008). What is implicit about implicit self-esteem? Journal of Research in Personality, 42(6), 1635-1640.

Pavlova, B., Uher, R., Dennington, L., Wright, K., \& Donaldson, C. (2011). Reactivity of affect and self-esteem during remission in bipolar affective disorder: An experimental investigation. Journal of Affective Disorders, 134(1-3), 102-111.

Rosenthal, S.A., \& Hooley, J.M. (2010). Narcissism assessment in social-personality research: Does the association between narcissism and psychological health result from a confound with selfesteem? Journal of Research in Personality, 44(4), 453-465.

Seger, C. R., Smith, E. R., \& Mackie, D. M. (2009). Subtle activation of a social categorization triggers group-level emotions. Journal of Experimental Social Psychology, 45(3), 460-467.

Usborne, E., \& Taylor, D. M. (2010). The role of cultural identity clarity for self-concept clarity, selfesteem, and subjective well-being. Personality and Social Psychology Bulletin, 36(7), 883-897. 